\title{
Archipel
}

ARCHIPEL Études interdisciplinaires sur le monde insulindien

99 | 2020

Varia

\section{Asahan Alham, Dendam Sejarah (Everlasting fostering of Revenge). Bandung: Ultimus, 2019, lvi-627 p. ISBN: 978-602-8331-76-0.}

Nico Schulte Nordholt

\section{(2) OpenEdition}

Journals

Electronic version

URL: http://journals.openedition.org/archipel/1934

DOI: $10.4000 /$ archipel.1934

ISSN: 2104-3655

Publisher

Association Archipel

\section{Printed version}

Date of publication: 15 July 2020

Number of pages: $314-317$

ISBN: 978-2-910513-83-2

ISSN: 0044-8613

Electronic reference

Nico Schulte Nordholt, "Asahan Alham, Dendam Sejarah (Everlasting fostering of Revenge). Bandung: Ultimus, 2019, Ivi-627 p. ISBN: 978-602-8331-76-0.", Archipel [Online], 99 | 2020, Online since 02 June 2020, connection on 15 March 2021. URL: http://journals.openedition.org/archipel/1934 ; DOI: https:// doi.org/10.4000/archipel.1934 
they had accepted Islam. When contextualising an Arabic prayer 'sadaqakum Allāh 'alayh tawakkalnā astaghfir Allāh rabbah' which literally means 'may Allah correct you, we submit everything to Allah, I ask forgiveness to Allah the God', the BDA text renders it as 'worship Wé Mappanyiwi' in Heaven while holding up both hands on earth'. In this example, Akhmar identifies three patterns of Bugis influence in the representation of Islam: linguistic influence, contextual translation, and ritual practices. Following Marriot's analysis, Akhmar recognises a sort of universalisation and parochialisation at the same time.

Readers looking for a fuller and more complex treatment of the processes of Islamisation need to adjust their expectations to the particular concerns of this book. Indeed, out of a total 566 pages, the explicit discussion of Islamisation only occupies about 26 pages. The study remains, however, an important and timely one. It successfully demonstrates some elements of Islam in this BDA text. This is a possibility which has not previously been sufficiently acknowledged by scholars working with La Galigo texts.

\section{References:}

Asad, Talal.1986. The Idea of the Anthropology of Islam. Washington: The Center for Contemporary Arab Studies (Georgetown University).

Eaton, R.M. 1993. The Rise of Islam and the Bengal Frontier 1204-1760. Barkeley: University of California Press.

Saenong, Faried F. 2016. Making Sense of Muslim Societies: Belief and Praxis in Bantaeng. $\mathrm{PhD}$ Thesis. Dept. of Anthropology. Australian National University.

Wahid, Abdurrahman. 1989. Pribumisasi Islam. In M. Azhari and AM Saleh (eds.). Gus Dur Menjawab Kegelisahan Rakyat. Jakarta: P3M.

Faried F. Saenong

Asahan Alham, Dendam Sejarah (Everlasting fostering of Revenge). Bandung: Ultimus, 2019, lvi-627 p. ISBN: 978-602-8331-76-0.

This fist-thick volume with largely literary work of Asahan Aidit (born 1938) was compiled by the editor, Bilven, of the publishing house Ultimus in Bandung, West Java. This publisher specializes in so-called samizdat (underground) Indonesian literature. With this volume the editor intended to commemorate the 80th birthday of Asahan, who, therefore, had no say himself in its content, neither in the choice of the title of this compilation. Even his name, Asahan Alham, instead of his family name, Asahan Aidit, was chosen by the editor/publisher. While, in the very short autobiography added to this volume, Asahan signed as: Asahan Aidit!

As a younger brother of D.N. Aidit, the last Chairperson of the Indonesian Communist Party $(P K I)$, the greatest communist party outside China and the Soviet Republic till 1965, Asahan had to carry the heavy burden his family experienced. Already for 55 years. 
On September 30th, 1965, one of the bloodiest massacres in human history erupted in the Indonesian Archipelago. An estimated half a million till one million members, or alleged members of PKI, were brutally killed. Amongst others, Asahan's brother D.N. Aidit. And hundreds of thousands persons, sometimes only just relatives of members, or just alleged members, were imprisoned for many years. In most cases without any form of prosecution.

Fortunately, Asahan Aidit escaped such a fate due to the fact he happened to study linguistics since 1962 in Moscow. As an exile, his fate was inseparably intertwined with the tragic fate of his family, and to that of the communist party in Indonesia in general. From Russia he fled to Vietnam, where he accomplished successfully his $\mathrm{PhD}$ in linguistics in the Vietnamese language. And, since 1984, he lives and writes in a small village near Amsterdam.

As relative of the Chairperson of $P K I$, his work as an author was regarded as communist literature. An ideology strictly forbidden during Suharto's New Order regime, and, notwithstanding the Reformasi in the years after Suharto was forced to step-aside in 1998, till today.

Therefore, it is a token of civil courage that Bilven dared to publish Asahan's work to honour one of Indonesia well-known writers who has been forced to live in exile for so many decades.

This volume, published in 2019, consists of a wide range of literary works: eighty-one (!) poems, of which 11 are added with its Dutch or English translation, and 8 are either in Dutch or English only; approximately 350 haiku, and 37 short stories or articles. In addition to this work by Asahan the editor invited several persons, who are very much familiar with Asahan and his work, to write a kind of introduction. The one Dr. Henri ChambertLoir wrote is in particular illuminating to this volume. Amongst others, he aptly situates Asahan's literary work as belonging to a specific genre of autobiography that can best be described as "fictionalization of real facts" or "self-fictionalization" (pp. xviii-xx).

Next to all of this, this volume has three appendices by which Asahan's literary work is even more enlightened. One contains an interview with him in the well-known Indonesian magazine Tempo, December 2007. The other two are re-prints of articles in English, respectively on his life as an author in exile, by David T. Hill, and the other one about Asahan's four novels reviewed by Henri Chambert-Loir. This last article, earlier published in English in Archipel (2016) is followed by its Indonesian version.

Allegedly, a large part of his late work compiled in this volume Asahan himself had lost due to frequently being hacked by radical Islamic groups who severely oppose so-called communist publications. It was, therefore, a great surprise and relief to the author that by the occasion of his 80th birthday, so many of his own lost 'literary children' were revived to him again. And with him, the reader of this voluminous compilation can be relieved and surprised 
as well that, due to the efforts of the editor, this 'lost' part of Asahan's literary work is now available again, in print!

Amongst the Indonesian exile literature Asahan's work is unique. It covers novels, short stories and poems, and also articles mostly dealing with rather controversial items. But the author is in particular unique amongst his fellow authors since, except for his good friend, the late poet Agam Wispi, hardly any other Indonesian writer has ever composed haiku in this language.

As stated above, not less than 350 haiku (!) are presented in this volume. Although in Indonesian literature, and even more so in the oral tradition, the pantun is a well-known genre, it differs essentially from the haiku. Not only in form, the pantun consisting of four verses while the haiku has three always, but foremost in content. The pantun, being an epigram, often spontaneously erupts during festivities in the form of a competition between several poets or even laymen, the haiku, mostly, expresses emotions that are structured according to strict rules and rhythm. Therefore, for composing a haiku an author needs special skills. In one of his articles in this volume, however, Asahan dealt with these problems of composing haiku in a complete different language and culture than the original Japanese structure stipulates. It turns out that - as in many more spheres of life and views - he has freed himself from the formal strait-jacket of the classical Japanese haiku, and instead of the 5-7-5 rule as number of syllables in each verse, he prefers the flexibility of modern haiku. So, he often switches to other formats. Nevertheless, he nearly always keeps in mind the genuine spirit of haiku, i.e. to "broadly widen the possibility of interpretation to the reader" (p. 417). Hence, for a reader who is sensitive to the rhythm of the syllables of the three verses a haiku consists of, and who is open-minded to its content - as the reviewer is - he will admire many of Asahan's haiku which contain a strong flavour of humour, although there are also several ones expressing deep bitterness and sorrow.

Both emotions are, given Asahans trajectory as a writer, also often revealed in his poems and short stories. However, the overarching emotion in his literary work is "revenge".

Only after I had read the poem with the same title in this volume (p. 3), could I see how aptly the title for this volume was chosen. Literally, Dendam Sejarah could be translated as: Historic Revenge. However, in my view, this translation does not properly reflect the specific position Asahan Aidit, or for that matter Asahan Alham, claims to possess in his life-journey and amidst his fellow authors in exile. In my reading of Asahan's literary work "revenge" is not a negative form of energy but a strength to "carry on" (p. 3). Moreover, for Asahan, revenge is a source of inspiration to counter the people's enemies, as he stated in his very short autobiography (p. v).

After reading this poem, I prefer to translate Dendam Sejarah as: "Everlasting fostering of revenge". To illustrate my stand I refer to two 
strophes (p. 3), and in particular to the last verse of the first strophe, and the last two verses at the end of this poem he wrote in 2008 (English version by the reviewer):

\section{Dendam Sejarah}

Tak usah kaubelah hatiku

Karena telah kukatakan sendiri

Ini dendam yang belum terbalas

Aku bahagia dan tenang bersamanya

Kan kubawa hingga jasad ini menjadi tanah.

(.....)

Dendam adalah kekuatan dan cinta

Dendam adalah solidaritas dan masa depan

Dendam adalah naluri persaudaraan yang berbinar

Dendam adalah mahkamah pengadilan dosa

Aku merasa hidup

Karena aku mengemban dendam.

\section{Everlasting fostering of revenge}

No need to scrutinize my heart

Because I told myself already

This revenge is not yet repaid

I am pleased and restful

To carry it on till my body will be dust

(......)

Revenge is strength and love

Revenge is solidarity and future

Revenge is the instinct of sparkling brotherhood

Revenge is the last judgment of sin

Ifeel alive

Because I foster revenge.

\section{Nico Schulte Nordholt Indonesianist}

Ajip Rosidi, Surat-surat ti Jepang (Letters from Japan, volumes 1-4), chosen by Usep Romli. Bandung: Kiblat, 2017, 577 p. ISBN: 978-979-8004-04-9, 978-979-8004-08-7, 978-979-8004-09-4, 978-979-8004-10-9.

Over the course of his brilliant career Ajip Rosidi (b. 1938) has worn many hats: poet, playwright, novelist, researcher, translator, journalist, ethnomusicologist, biographer, publisher, editor and cultural bureaucrat. If I were to reduce these many activities to a single, over-arching program, his contribution might best be summarised as follows: quite early in his career he 